\title{
The 19th-century origins of nuclear deterrence
}

\section{Gordon Fraser}

Abstract: This article suggests that understanding the unspoken assumptions of nuclear weapons policy depends on understanding late-19th-century literary accounts of superweapons, which prefigured the atom bomb. Such accounts were utopian. They envisioned world peace brought about through a technological breakthrough, one that would allow a single nation to achieve absolute hegemony. This article demonstrates the links between 'future war' stories written by authors such as Jack London, Frank Stockton, and Roy Norton, on the one hand, and the nuclear deterrence reasoning of US leaders such as Harry Truman, Richard Nixon, and Donald Trump, on the other. The nuclear device realises the dream of a technology suited to coercive diplomacy and little else, and as a result it traps 21 st-century nation-states in a set of relations devised by thinkers in the 19th century. This article suggests, ultimately, that the danger of reverting to the logic of 19 th-century coercive diplomacy will remain as long as nuclear weapons do.

Keywords: Nuclear weapons, deterrence, superweapons, future war, utopian, atom bomb, coercive diplomacy, Harry Truman, Richard Nixon, Donald Trump.

Note on the author: Gordon Fraser is the author of Star Territory: Printing the Universe in Nineteenth-century America, forthcoming from Penn Press. He is a lecturer and presidential fellow at the University of Manchester, and his scholarship has appeared in journals such as PMLA and American Quarterly.

(C) The author(s) 2020. This is an open access article licensed under a

Creative Commons Attribution-NonCommercial-NoDerivs 4.0 Unported License 
What if there were a weapon so powerful that it could end hundreds of thousands of lives in a single flash, poisoning groundwater, killing crops, and annihilating a nationstate's productive capacity? Today, academics and policymakers grapple with the ongoing reality of such weapons, and nuclear non-proliferation is the subject of scholarly debate and international agreements. But in the late-19th and early-20th centuries, before the creation of the first nuclear device, cultural producers nonetheless imagined that human beings might one day possess such weapons. Major novelists, from the now-famous Jack London (1876-1916) to the then-bestselling Frank Stockton (1834-1902), wrote stories depicting such superweapons. Popular magazines, such as McClure's, imagined contexts that might justify the use of such weapons. ${ }^{1}$ And major publishing houses, such as Macmillan and Houghton Mifflin, produced books examining how and when such weapons might be deployed by world powers. ${ }^{2}$ These cultural producers, in short, imagined a global regime in which the possession of superweapons by a small handful of nation-states would produce a global monopoly on violence, a condition Elaine Scarry has called 'thermonuclear monarchy'. ${ }^{3}$

This essay will suggest that understanding the cultural logic of late-19th-century superweapon fantasies is critical to understanding the assumptions that underpin nuclear policy today. Nineteenth-century publishers, editors, and authors hoped that the advent of superweapons would mark the end of war by ending politics itself. The possibility of absolute violence, they imagined, would be so unthinkable as to prevent violence altogether. Indeed, after the nuclear bombings of Hiroshima and Nagasaki, policymakers themselves referred to the atomic device as an 'absolute weapon'. 'The search of science for the absolute weapon has reached fruition in this country', US presidential advisor Bernard Baruch (1870-1965) declared in a speech to the United Nations Atomic Energy Commission in 1946. ${ }^{4}$ For him-as for many others - the 'absolute' nature of nuclear violence could paradoxically prevent violence altogether. ${ }^{5}$ Contesting the will of a nuclear power would be tantamount to national suicide, and so the world's lone nuclear state would be able to set the terms of the coming peacebanning the weapons, eventually. The reality of the nuclear age has been far different.

\footnotetext{
${ }^{1}$ London (1910), Stockton (1889).

${ }^{2}$ Barnes (1904), Nicolson (1932).

${ }^{3}$ Scarry, (2014: especially $\left.1-27.\right)$

${ }^{4}$ Baruch (1946).

${ }^{5}$ The phrase 'absolute violence' has a long tradition in postcolonial theory, beginning with Franz Fanon's The Wretched of the Earth (2004 [1961]), wherein he refers to a form of violence that 'represents the absolute praxis'. The key to this form of absolute violence is that it is 'irreversible'. Fanon, however, is interested in violence by the colonised against colonisers. As I use the phrase, 'absolute violence' refers to acts that are irreversible (as in Fanon's writing) and out of proportion with the aims and objectives of a particular conflict. The absolute violence of the 'absolute weapon' ends war by ending the lives of the people who might make war in the future. See Fanon (2004: 44) and Day (2015).
} 
The era of nuclear 'deterrence' has played host to different forms of warfare (the rise of transnational terrorism by non-state actors, for instance), and yet this period has hardly represented an end to warfare itself. Moreover, the possibility of a nuclear catastrophe has not actually diminished. Rather, the risk of nuclear conflict has become intermittently visible. Ward Wilson even suggests that the acquisition of nuclear weapons by small and relatively weak nation-states has likely increased the possibility that a military or non-state group will detonate a nuclear device. ${ }^{6}$

Yet policymakers, military strategists, and politicians continue to subscribe to a 19th-century belief that superweapons prevent wars through their deferred potential for absolute violence. This belief has been repeated by President Donald J. Trump, for instance, who explained to The New York Times in March 2016 that he 'always felt ... that nobody would ever use [nuclear weapons] because of the power'. ${ }^{7}$ This belief has been repeated, moreover, by the former commander of US Strategic Command, General C. Robert Kehler, who suggested in a recent Daedalus article that 'nuclear weapons will continue to cause leaders to pause and consider the risks and consequences of escalation before they act' ${ }^{8}$ In suggesting that superweapons contain and prevent violence, both are repeating a belief - a mistaken belief, I suggest - that cultural producers first articulated in the 19th century. In essence, these writers, editors, and publishers imagined with longing what Scott Sagan and Jeffrey G. Lewis have called the 'monstrous immorality' of nuclear weapons, suggesting that the catastrophic violence unleashed by such weapons would reduce belligerent states to subjection. ${ }^{9}$

Consider, for instance, the ending of Frank R. Stockton's popular novel, The Great War Syndicate (1889). In that novel, the 'motor-bomb', a prefiguration of the nuclear device, could destroy whole cities in a single blast. Even at a great distance, the device caused damage. Stockton writes:

Thousands of panes of glass in [an adjacent] city and in houses for miles around were cracked or broken, birds fell dead or stunned upon the ground, and people on elevations at considerable distances felt as if they had received a blow.

When nation-states in this novel face the possibility of such absolute violence, they submit to US and British imperialism. After the development and use of this weapon, 'all the nations of the world began to teach English in their schools, and the Spirit of Civilization raised her head with a confident smile'. ${ }^{10}$ In essence, the dream of 19th-century deterrence is a dream of peace through hegemony.

\footnotetext{
${ }^{6}$ Wilson (2007: 179).

${ }^{7}$ Haberman \& Sanger (2016).

${ }^{8} \operatorname{Kehler}(2016: 60)$.

${ }^{9}$ Sagan \& Lewis (2016: 63).

${ }^{10}$ Stockton $(1889:$ 64-5, 191).
} 
In their potential for harm, then, nuclear devices represent a dream for the future that comes to us from the distant past. In the 19th century, writers such as Stockton first formulated a narrative in which the potential for absolute violence paradoxically deferred violence altogether. Wholly out of proportion with the contemporary legal regime governing armed conflict, nuclear weapons are instead continuous with 19th-century fantasies of future war. During that period, cultural producers manufactured the fiction that peace could be achieved - indeed, could only be achievedthrough the deferred possibility of catastrophic violence. Superweapons would only have to be used once, they argued. After their use, people the world over would recognise the danger of such devices. War would end. For the weapon's inventors, vulnerability itself would disappear.

Nuclear weapons have not enabled states to achieve this impossible fantasy. Yet traces of this implausible 19th-century faith in the power of superweapons to produce relations of hegemony and subjection remain implicit in the still-accepted doctrine of nuclear deterrence. And it is to this implicit faith that I will turn in the pages to follow.

\section{ABSOLUTE VIOLENCE AND THE DREAM OF 'UNIVERSAL LAW'}

En route to Potsdam in 1945, President Harry Truman (1884-1972) hoped for a lasting peace. In an often-repeated story, the journalist A. Merriman Smith (1913-70) reported that Truman fished from his pocket 'a worn piece of paper', which he claimed to have carried with him continuously since 1910 . Written on this paper were ten lines from Alfred Lord Tennyson's (1809-92) 'Locksley Hall' (1835), lines concluding with the emergence of a 'parliament of man' and the end of war. This, Truman explained, was the origin of his hope for 'a republic of the world', the then-emergent United Nations. ${ }^{11}$ Indeed, Truman had spent his early life immersed in progressivist narratives about a future of global peace, narratives that permeated the literary and periodical culture of his young adulthood. Nearly all of these narratives shared two premises, both illustrated by 'Locksley Hall'. First, global peace would only follow from catastrophic violence against unarmed civilians. In Tennyson's poem, the speaker hears 'the heavens fill with shouting' as a 'ghastly dew' rains down from 'airy navies grappling in the' sky above. In essence, Tennyson predicted the firebombing campaigns that Truman would have recognised as a key element of the Second World War. Second, such violence would produce a global order based upon racial subjection.

${ }^{11}$ Smith (1946: 286). For Truman on the United Nations as a kind of global republic, see Truman (1945). For more on future war fictions, see Franklin (1989). 
In 'Locksley Hall', a new 'universal law' results in the end of war, but the speaker of Tennyson's poem takes the occasion of world peace as an opportunity to imagine himself, 'Deep in yonder shining Orient', where he will be free to 'take some savage woman' who 'shall rear my dusky race'. ${ }^{12}$ In short, peace provides the occasion for the kind of imperialist adventurism - including sexual adventurism - that characterised the 19th-century scramble for raw materials and labour. Notably, Truman did not copy down the portion of the poem describing the speaker's sexual exploits. But Truman was hardly unaware of how 19th-century writers had linked the hope of peace through absolute violence with fantasies of racial subjection.

Indeed, around the time Truman copied 'Locksley Hall' onto a small slip of paper and stowed it in his wallet, he likely read another account about the imminent outbreak of global peace. This account, written by the popular novelist Jack London, appeared in McClure's Magazine, a periodical to which Truman subscribed. (He observed in May 1913 to his future wife, Bess Wallace (1885-1982), that he would 'have to renew my subscription to McClure's now so I won't miss a number'. ${ }^{13}$ ) In London's short story, the rise of China as a world power results in a global war, which begins and ends with the use of biological weapons against Chinese civilians. Airplanes drop 'a score of plagues' onto Chinese cities and villages, turning much of Asia into a 'howling wilderness'. This strategy, London explains, emblematises 'ultra-modern war, twentieth century war, the war of the scientist and the laboratory'. Its result, ultimately, is the death of every last person in China and a new global regime in which 'all nations solemnly pledged themselves never to use against one another the laboratory methods of warfare they had employed in the invasion'. ${ }^{14}$ As in 'Locksley Hall', a technologically sophisticated total war against a civilian population results in the outbreak of world peace. Readers knew McClure's Magazine for its commitment to progressive, 'muck raking' journalism. Ida Tarbell's (1857-1944) exposé of the Standard Oil Company in 1902 is a famous example. ${ }^{15}$ London's story, despite its shocking advocacy of genocide, in many ways fit with the periodical's progressive politics. London imagined a future regime of global peace, a periodic topic of discussion in the pages of McClure's. ${ }^{16}$

In short, the decision by Truman and the Pentagon to target Hiroshima and Nagasaki was continuous with a long-standing narrative suggesting that the path to

\footnotetext{
${ }^{12}$ Tennyson (1842: 104, 105, 109).

${ }^{13}$ Letter from Harry S. Truman to Bess Wallace, 27 May 1913 (Family, Business, and Personal Affairs Papers. Harry Truman Presidential Library and Museum).

${ }^{14}$ London (1910: 312, 314).

${ }^{15}$ Tarbell (1904: passim). Tarbell's history had been serialised in McClure's before it appeared in a 1904 book.

${ }^{16}$ See, for instance, McClure's (1910).
} 
peace lay through the violence of total war and of superweapons. The minutes of the Target Committee - the government group tasked with selecting targets for the atomic bomb - reveal that its members dismissed the possibility of demonstrating the power of the nuclear device away from human populations. 'It was agreed', the minutes of May 1945 report, 'that the psychological factors in the target selection were of great importance.' The initial explosion, the committee decided, must be 'sufficiently spectacular for the importance of the weapon to be recognized when publicity on it is released'. ${ }^{17}$ Captain William 'Deak' Parsons (1901-53), associate director of the programme's ordinance division, put this observation more bluntly: '[T]he reaction of observers to a desert shot would be one of intense disappointment', he wrote. 'Even the crater would be disappointing'. ${ }^{18}$ Behind these calls for spectacular violence against civilian populations lay a deep faith in the power of such violence to end conflict, and in the future to deter it. As atomic scientist J. Robert Oppenheimer (190467) explained in subsequent testimony, he believed that it was the intention of the United States statesmen who went to Potsdam to say something [about the atomic weapon] to the Russians', and that the Manhattan Project scientists 'were under incredible pressure to get it done before the Potsdam meeting'. Truman, travelling to the summit and imagining the realisation of Tennyson's 19th-century dream of peace through violence, could share the news with Soviet premier Joseph Stalin (1878-1953) that the United States 'had a new weapon which we planned to use'. ${ }^{19}$ Tennyson and London had predicted that spectacular violence would deter future conflict by establishing a new, hegemonic world order, and the United States was now in possession of the means by which it might achieve such hegemony.

Numerous historians, journalists, and activists have criticised the myopia of the Pentagon's nuclear war planners, who failed even to seriously consider the warnings of those who cautioned against the use of nuclear weapons on civilian population centres. ${ }^{20}$ War planners were convinced of the need to use the nuclear device against large numbers of human beings. In order to understand why, it is useful to examine how works of art - particularly works of prose fiction - produce conventional wisdom. Literary scholars have long been concerned with the relation between readers and the material world they inhabit, and with the ways texts provide what Robin Bernstein

\footnotetext{
${ }^{17}$ Minutes of the second meeting of the Target Committee, Los Alamos, 10-11 May 1945 (U.S. National Archives, Record Group 77, Records of the Office of the Chief of Engineers, Manhattan Engineer District, TS Manhattan Project File '42-'46, folder 5D Selection of Targets, 2 Notes on Target Committee Meetings).

${ }^{18}$ William S. Parsons to Leslie Groves, 25 September 1944 (Papers of William S. Parsons, Library of Congress. Quoted in Malloy 2008: 61).

${ }^{19}$ United States Atomic Energy Commission (1954: 31-2). See also Franklin (1989: 151).

${ }^{20}$ See, for instance, Ham (2015), Compton (1946).
} 
calls 'implied' scripts to future behaviour. ${ }^{21}$ The origins of this analysis date to foundational theorists of 'reader response', such as the German critic Wolfgang Iser. For Iser, the act of reading prompts a reader with 'someone else's thoughts'. Yet readers do not simply take up these thoughts as their own. Rather, Iser explains:

our unformulated faculty for deciphering those thoughts is brought into play-a faculty which, in the act of deciphering, formulates itself. Now since this formulation is carried out on terms set by someone else, whose thoughts are the theme of our reading, it follows that the formulation of our faculty for deciphering cannot be along our own lines. ${ }^{22}$

Reader and text enter into a relation with one another, but the relation is an asymmetrical one. A work of fiction invites readers to travel along particular wellworn paths, to linger over associations to which they have become habituated, and to dwell in thematic places made comfortable by lengthy habitation. Fictions do not make demands of their readers, but they do make persuasive suggestions and compelling invitations. Over time, fictions exert a shaping influence on our relation with the world.

Consider, then, what Pentagon war planners and policymakers had been primed to expect from the use of a superweapon against a population of East Asian civilians. In London's popular story, the genocidal violence of the 'the scientist and the laboratory' produced a future in which all 'nations solemnly pledged themselves' to peace. ${ }^{23}$ This was akin to the story told by Tennyson in 'Locksley Hall' and Stockton in The Great War Syndicate, but it was also akin to numerous other stories from the period. In Roy Norton's (1869-1942) The Vanishing Fleets (1907), first serialised throughout the United States by the Associated Sunday Magazines, a sneak attack by the Japanese first throws the United States military on its heels. But the US invention and production of weapons that harness the power of radioactivity - called 'peacemakers'grants the United States the ability to 'not only conquer the world, but destroy the inhabitants of other nations'. Reluctant to use this power unjustly, the president of the United States establishes a global treaty that fixes national borders in their 1907 configurations and inaugurates a period of world peace. ${ }^{24}$ At the time, the Associated Sunday Magazines reached a total of about one million subscribers in Chicago, St. Louis, Philadelphia, Pittsburgh, New York, Boston, Washington, Minneapolis, and Denver. ${ }^{25}$ Stories such as this permeated US culture in the decades prior to the

\footnotetext{
${ }^{21}$ Bernstein (2009: 71, 74).

${ }^{22}$ Iser (1974: 294).

${ }^{23}$ London (1910: 314).

${ }^{24}$ Norton (1908: 340, 350).

${ }^{25}$ Magazine of Business (1908).
} 
Second World War, from the 19th century into the first half of the 20th. ${ }^{26}$ These stories, I suggest, shaped and even produced a kind of common sense about superweapons and about totalising forms of violence that could end thousands - or even millions - of lives. ${ }^{27}$

Yet, just as the superweapon narratives had a recognisable structure, so too did the weapon itself have a form that shaped assumptions about its possible use. In its deferred potential for producing absolute violence, the nuclear weapon was the manifestation of a 19th-century fantasy. Manhattan Project researchers were as immersed in this fantasy as policymakers. Indeed, atomic scientist Leo Szilard (1898-1964) ordered a copy of The World Set Free (1914), a novel by H. G. Wells (1866-1946), for the Manhattan Project library. (In this novel, Wells predicted that technology would make war 'impossible', but only after 'atomic bombs burst' in the 'fumbling hands' of belligerents. ${ }^{28}$ ) Manhattan Project scientists, in essence, realised a desire first articulated by 19 th- and early-20th-century writers.

But the form of the weapon imagined by these writers presents a problem for policymakers today. In order to understand this problem, it will be helpful to consider how forms work across time and across contexts. For literary scholar Caroline Levine, the key to understanding form lay in understanding its 'affordances'. Borrowing this term from design theory, Levine explains that every 'shape or pattern, social or literary, lays claim to a limited range of potentialities'. She goes on: 'Enclosures afford containment and security, inclusion as well as exclusion. Rhyme affords repetition, anticipation, and memorization. ... [A]nd narratives afford the connection of events over time. ${ }^{29}$ Thinking about the form of the superweapon, then, reveals the problem. Such weapons have only two affordances, or potentialities: deferred threat and total annihilation. They are extraordinarily inflexible in this regard. The authors of superweapon fictions, from London to Stockton, found this inflexibility useful. By providing only two obvious potentialities, the superweapon would impose an immutable order upon the political world. The inflexible form of the superweapon-made manifest by the nuclear device - persists into the present, arming 21st-century political actors with a weapon once imagined by 19 th-century writers, editors, and publishers.

\footnotetext{
${ }^{26}$ The foundational study of this phenomenon remains that of H. Bruce Franklin (1988: especially 19-53).

${ }^{27}$ My use of 'common sense' here recalls the work of the foundational Marxist scholar Antonio Gramsci, for whom 'common sense' was the means by which people practise an 'everyday philosophy' that aligns contradictory and inconsistent views. For a discussion of Gramsci's formulation of 'common sense', see Chun (2017: 35-6).

${ }^{28}$ Franklin (1988: 134), Wells, (1914: 117).

${ }^{29}$ Levine (2015: 6-7).
} 


\section{THE FORMAL CONSTRAINTS OF NUCLEAR FICTIONS}

The second half of the 20th century was not marked by global peace. It was marked by the Cold War and a condition Lester Pearson (1897-1972) in 1955 called the 'balance of terror' ${ }^{30}$ Nuclear weapons proliferated: to the Soviet Union (1949), the United Kingdom (1952), France (1960), the People's Republic of China (1964), Israel (1963 or 1967), South Africa (1979-91), India (1974), Pakistan (1988), and North Korea (2006). ${ }^{31}$ The United States never achieved the hegemonic peace that 19th-century cultural producers had imagined. With the perspective of hindsight, the reason for this failure is obvious. Nineteenth- and early 20th-century writers had imagined that superweapons would inaugurate a kind of millennium - a period after history, politics, and conflict. The absolute violence unleashed by such weapons would reduce belligerent states to subjection. Yet, as political scientist Robin Markwica observes, the outcomes of coercive diplomacy are not solely shaped by threat and fear. The leaders of a nation-state experiencing coercion react to their fear, certainly, but also act on feelings of anger, hope, pride, and humiliation. ${ }^{32}$ The threat of violence - even violence as absolute and inescapable as that of nuclear annihilation - does not necessarily produce subjection and terror among those threatened. It produces, instead, defiance and indignation. The leaders of weaker nation-states scramble to acquire weapons or to produce asymmetric means of contesting the will of nuclear states.

Yet, while no reasonable policymaker or political theorist would argue that nuclear weapons produced or could produce the hegemony predicted by writers such as Tennyson, Stockton, London, or Norton, many continue to subscribe to the belief that nuclear weapons prevent wars. I began this essay with two very different examples of this thinking: that of the former head of US Strategic Command, General C. Robert Kehler, and that of President Donald J. Trump, both of whom describe nuclear weapons as an important part of the US arsenal. Their theories of deterrence-the former drawn from careful study and the latter only partly articulated - demand separate analysis, although I suggest that both can be traced to 19th-century fictions. In different ways, each defends the continued deployment of nuclear weapons. In both cases, moreover, the defence of this deployment reveals the constraints placed upon US policymakers by the 19th-century form of the weapon itself.

Consider, as a point of departure, General C. Robert Kehler's recent Daedalus essay on 21st-century nuclear deterrence. As the head of US Strategic Command, Kehler was responsible for implementing US nuclear weapons policy. Kehler's writing,

\footnotetext{
${ }^{30}$ Quoted in Gallagher (2013: 105).

${ }^{31}$ Bleek (2017: 8).

${ }^{32}$ Markwica (2018: 7).
} 
moreover, makes clear that the actual nuclear war plans of the United States (many of which remain classified) do not match popular fictions about nuclear war, past or present. 'Despite what is still commonly heard in public discourse', Kehler observes, 'the United States long ago rejected the intentional targeting of cities and civilian populations with nuclear weapons. ${ }^{33}$ In the potential use of these weapons, the United States abides by an international legal regime known as the Law of Armed Conflict, which mandates that militaries distinguish between lawful combatant targets and unlawful noncombatant targets, that the actions they take are proportional to their military objectives and governed by military necessary, and that militaries limit unnecessary suffering. ${ }^{34}$ Moreover, Kehler adds, nuclear weapons have constrained and limited the war-making capacities of major powers. He writes:

Although it is far too simplistic to say that nuclear weapons alone have prevented major war, the evidence is compelling that they fundamentally changed the notion of warfare between major nations in August 1945 and that their deterrent effects have constrained the scope and scale of conflict ever since.

Kehler explains that nuclear weapons place limits on potential conflicts before they begin, constrain political actors once a conflict has broken out, and prevent nationstates from attempting to 'use the threat of nuclear escalation to reverse' the outcome of a conflict after it has been resolved..$^{35}$

But nuclear weapons were not first imagined as tools of deterrence. They were imagined as tools of hegemony. And their origins in the fictional dream of global dominance continues to shape the role they play in geopolitics. As Kehler observes, 'Adversaries have watched the United States project conventional military power with relative impunity for over twenty years and are pursuing "integrated strategic deterrence" strategies to reduce the likelihood of our intervention in regional affairs. ${ }^{36}$ The primary adversary to which Kehler refers is the People's Republic of China, a nationstate targetted in many of the nuclear weapons fantasies of the early 20th centurymost notably London's 'Unparalleled Invasion'. Yet other nations, including the Democratic People's Republic of Korea (DPRK or North Korea), have also produced a nuclear deterrent. Moreover, even as US military hegemony has sent adversaries scrambling for nuclear deterrents, United States nuclear policy continues to deploy the threat of nuclear attack as a means of coercing those adversaries. Kehler's insistence that nuclear weapons have 'constrained the scope and scale of conflict' since the end of the Second World War leaves unspoken the implication that nuclear weapons

\footnotetext{
${ }^{33}$ Kehler (2016: 58).

${ }^{34}$ Lee $(2015: 13,35,103)$.

${ }^{35}$ Kehler (2016: 52).

${ }^{36}$ Kehler (2016: 53 n. 9).
} 
contain the potential for absolute violence: they enable one nation-state to threaten many others with a doom that can be deferred indefinitely. ${ }^{37}$ But this threat is paradoxical. As Sagan and Lewis observe, 'the unstated threat to inflict high levels of civilian punishment' uneasily coexists with 'the official promise to respect the law of armed conflict and "minimize collateral damage" , ${ }^{38}$ While those responsible for planning and implementing nuclear weapons policy would insist that inflicting 'high levels of civilian punishment' is not, in fact, the goal of nuclear weapons policy, it nonetheless remains the case that nuclear weapons are not particularly suited for any other task.$^{39}$ From the 19th century onward, these weapons were imagined as a means of destroying entire cities and eliminating whole populations. By design, the form of the superweapon limits its possible functions.

Despite the promises of nuclear policymakers to abide by the Law of Armed Conflict, nuclear weapons themselves continue to be recognised for what they were first imagined to be: tools of mass murder and coercive diplomacy. The weapon's form invites a reversion to the 19th-century logic of hegemony through absolute violence. We need look no further than President Trump's recent statements about nuclear weapons to recognise the 19 th-century reasoning at work in his thinking about nuclear war. On 8 August 2017, he suggested that, if leaders of the DPRK continued to make threats against the United States, they would be 'met with fire and fury like the world has never seen'. ${ }^{40}$ On 2 January 2018, Trump suggested that his 'Nuclear Button' was 'much bigger \& more powerful' than that of North Korean leader Kim Jong-Un. ${ }^{41}$ For many, these statements have become as notorious as President Richard Nixon's (1913-94) observation that 'I can go into my office and pick up the telephone and in twenty-five minutes seventy million people will be dead. ${ }^{32}$ Yet these statements have been regarded as irresponsible because they are, in a literal sense, true. ${ }^{43}$ Nixon indeed had the authority — as a practical matter if not under international law — to kill seventy

\footnotetext{
${ }^{37} \operatorname{Kehler}(2016: 52)$.

${ }^{38}$ Sagan \& Lewis (2016: 63).

${ }^{39}$ As Ward Wilson writes: 'There's no question that nuclear weapons are very dangerous. It's just not clear that they are very useful. The question is, why would you want to keep a technology that's very dangerous but not very useful?' (Wilson 2013).

${ }^{40}$ Bierman (2017). As Fred Kaplan observes, this statement echoed one made by President Harry Truman more than seven decades earlier (see Kaplan 2020: 1).

${ }^{41}$ Trump Twitter Post, 2 January 2018, 4:49 PM, https://twitter.com/realDonaldTrump/status/ 948355557022420992?- ref_src=twsrc $\% 5$ Etfw\&ref_url=https $\% 3 \mathrm{~A} \% 2 \mathrm{~F} \% 2 \mathrm{Fwww}$. washingtonpost.com $\%$ 2 Fnews $\% 2$ Fworldviews $\% 2$ Fwp $\% 2$ F $2018 \% 2 \mathrm{~F} 01 \% 2 \mathrm{~F} 16 \% 2 \mathrm{Fnorth}$-korea-calls-trump-a-lunatic-and-aloser-in-response-to-nuclear-button-tweet $\% 2 \mathrm{~F} \& \mathrm{tf}$ w_creator=rick_n\&tfw_site $=$ WashingtonPost (accessed 22 April 2018).

${ }^{42}$ Quoted in Scarry (2014: 14).

${ }^{43}$ Larison (2017).
} 
million people. And while Trump does not literally possess a 'Nuclear Button', he is nonetheless correct in observing that 21st-century nuclear war on the Korean Peninsula would be unprecedented. Contemporary nuclear warheads are many times as powerful as those used to kill Japanese civilians and combatants in the final months of the Second World War, and renewed conflict in Korea could potentially lead to a wider conflagration.

Trump and Nixon are outliers, then, because they have been unwilling to speak in euphemism about the catastrophic — even absolute - nature of the violence unleashed by nuclear weapons. As Scarry writes of Nixon's observation, it 'was a stark-but completely accurate - description of presidential power' ${ }^{44}$ Likewise, the vividness of Nixon's language, and of Trump's, reveals not a misunderstanding about nuclear weapons, but a recognition of their power to condemn millions of human beings to death. In their directness, Trump and Nixon remind us that a United States president - now or in the future-might well become the greatest mass-murderer in human history. ${ }^{45}$

The statements also provide a reminder that the form of the nuclear device invites a reversion to the logic of 19th-century fictions about Great Power conflict. Trump's promise to unleash 'fire and fury like the world has never seen' made no pretence about how the possessors of nuclear weapons often hope that their possessions might produce a hegemonic peace. ${ }^{46}$ Trump describes a future in which nations submit to the will of the United States, not one in which all nations abide by a shared set of rules and norms. Nuclear weapons were first imagined as inaugurating precisely this future, this hegemonic peace. The 'peacemakers' of Norton's story and the 'motor-bombs' of Stockton's both produced an Anglo-American world order, but one that was imposed upon other nations. Superweapons, in these stories and in others, were a tool of coercive diplomacy.

Many of the reactions to Trump's statements on nuclear weapons have noted the distance between his thinking and long-standing norms of nuclear deterrence. Indeed, candidate Trump's apparent unfamiliarity with concepts such as the 'nuclear triad'the combination of land-based missiles, submarine-based missiles, and nuclear bombers, which ensures US second-strike capabilities - reveals Trump's inattentiveness to traditional deterrence theory. Yet Trump's thinking about nuclear weapons is indeed continuous with their deep origins in fiction. Nineteenth- and early 20th-century writers dreamed of a future in which the United States might engage in coercive diplomacy by threatening to use weapons with the potential to kill entire populations.

\footnotetext{
${ }^{44}$ Scarry (2014: 14).

${ }^{45}$ In the film Dr. Strangelove, President Muffley (Peter Sellers) protests that 'I will not go down in history as the greatest mass murderer since Adolph Hitler!' (Kubric (dir.) 1964).

${ }^{46}$ Bierman (2017).
} 
When Trump observes that 'for me, nuclear is just the power, the devastation is very important to me', he is highlighting the use of such weapons as tools of threat and coercion. ${ }^{47}$

\section{TH-CENTURY FORMS AND THE FUTURE OF DETERRENCE}

Nuclear policymakers repeat 19th-century assumptions because the nuclear device itself represents the fulfillment of an imagined 19th-century form. But literary and material forms do not exist in isolation. Cultural producers imagined that the superweapon - the 'motor-bomb', the 'ghastly dew', the 'peacemaker', the nuclear devicewas a form capable of imposing order because it was singular. One nation-state or a close collection of racially and politically similar allies would possess the weapon. Others would submit or commit collective suicide. But as superweapons proliferate, threats of absolute, totalising violence proliferate. These threats interrupt, disrupt, and reroute each other. ${ }^{48}$ Weaker nation-states seek nuclear weapons as a means of forestalling US attempts at regime change, alternatively preventing challenges by the United States or inviting them. ${ }^{49}$ Rather than producing hegemony, then, nuclear weapons produce uncertainty, confusion, and the potential for catastrophic accidents.

Despite this, policymakers continue to reiterate a 19th-century belief in the power of superweapons, such as the nuclear device, to produce relations of hegemony and subjection. The most recent Nuclear Posture Review by the US Department of Defense makes this clear. The Review authors explain:

For centuries prior to the era of nuclear deterrence, periodic and catastrophic wars among Great Powers were the norm, waged with ever more destructive weapons and inflicting ever higher casualties and damage to society. ... Since the introduction of U.S. nuclear deterrence, U.S. nuclear capabilities have made essential contributions to the deterrence of nuclear and non-nuclear aggression. The subsequent absence of Great Power conflict has coincided with a dramatic and sustained reduction in the number of lives lost to war globally. ${ }^{50}$

In essence, the US Department of Defense endorses the view-widely popular at the end of the 19th century and the beginning of the 20th - that the problem of Great Power conflict has a technological solution, the superweapon, and that the hegemony

\footnotetext{
${ }^{47}$ Berney (2015).

${ }^{48}$ Levine (2015: 47).

${ }^{49}$ In his speech to the United Nations, then-Secretary of State Colin Powell referred to 'Iraq's nuclear program' as justification of the subsequent coalition invasion (Powell 2003; see also McDevitt 2011).

${ }^{50}$ Mattis (2018: 16-17).
} 
of a single power will produce and maintain a lasting peace. The Review authors are correct to note that the total number of wartime fatalities as a percentage of the global population has fallen since the end of the Second World War, but this statistic tells us very little about the potential for future wartime fatalities. Measured against the sweep of history, seventy-five years is not a very long time. As Steven Pinker observes, if this long period of peace is a 'nuclear peace', then it is nothing more than 'a fool's paradise'- a period before nuclear catastrophe. (Pinker attributes the decline in violence to a set of humanitarian and civil rights revolutions, as well as to a larger set of pro-social changes in human societies. ${ }^{51}$ ) The Nuclear Posture Review, moreover, warns of multiple, catastrophic possibilities: the acquisition of nuclear weapons by a terrorist group, the possibility of a regionally limited nuclear war, and the possibility of nuclear attack against the United States by nations such as Russia, China, or North Korea. ${ }^{52}$ Even the Department of Defense acknowledges that present limits on violence are not indicative of future limits.

The authors of 19th-century fictions consistently maintained that superweapons would produce hegemony, and therefore produce peace. The persistence of this belief prevents citizens and policymakers from thinking clearly about the future of nuclear weapons. When policymakers subscribe to the view that the nuclear device can impose order on the world, moreover, they begin to emphasise what literary scholar and media theorist Lindsay Thomas has called a 'preparedness' paradigm. Thomas is particularly interested in the fields of emergency management and homeland security, which train first-responders with imagined catastrophic scenarios - the nuclear attack, the hurricane, the epidemic. In official documents, these first-responders emphasise 'detachment and repetition', not social transformation. The material effect of this paradigm, Thomas writes, is that it maintains 'the status quo by extending the always catastrophic present into the future'. ${ }^{53}$ Policymakers focus on what to do when a neighbourhood floods, for instance, but not on how to avoid building homes in a floodplain. The Nuclear Posture Review operates within precisely this paradigm. In laying out policy for the prevention of and response to nuclear catastrophe, it leaves unexamined fundamental assumptions about nuclear weapons. Yet these unexamined assumptions come down to us from a period long before the advent of these weapons - a period in which brinksmanship by Great Powers led to periodic, catastrophic, wars between nation-states. The superweapon was the fantasy of those who hoped to end Great Power conflicts by winning them. But victory in war is always provisional, and new and better weapons can only offer temporary tactical advantage. Tools of

\footnotetext{
${ }^{51}$ Pinker (2011: especially 268).

${ }^{52}$ Mattis (2018: VII, XVI, 30-2).

${ }^{53}$ Thomas (2016: 159, 161).
} 
domination do not produce lasting peace. They produce resentment, righteous anger, humiliation, resistance, and reprisal.

While US law and policy prohibit the intentional targetting of civilians, nuclear weapons remain a tool unsuited to any task except the commission of violence against millions. As Sagan and Lewis write, a nuclear strike that does not directly target non-combatants but does target a nation-state's ability to recover from the initial attack might well disrupt food production and cause famine, might well poison soil and groundwater for generations, might well cause state collapse and anarchic violence. ${ }^{54}$ The 'monstrous immorality' of nuclear weapons, Sagan and Lewis observe, keeps these devices forever out of step with the Law of Armed Conflict, depending as it does upon the principles of distinction between combatants and civilians, proportionality, military necessity, and the limitation of unnecessary suffering. ${ }^{55}$ The Department of Defense insists that nuclear weapons have made 'essential contributions' to the reduction of Great Power conflict and wartime fatalities in the post-1945 era. In essence, the DOD claims that US threats to deploy weapons of absolute violence, weapons that blur distinctions between combatants and civilians, and that unnecessarily impose extreme suffering upon millions, have intimidated the leaders of other nation-states. But even if this is true, even if nuclear weapons have imposed such a peace in the past, there is no guarantee that they will impose such a peace in the future.

The United States today remains constrained by a 19th-century dream of peace through hegemony - hegemony made manifest by the absolute violence of the 'absolute weapon'. ${ }^{56}$ The nuclear peace - the peace of which Truman spoke so admiringlywas the peace of empires. It was a ceasefire between Great Powers that permanently enshrined their division of and dominion over the earth. The dream that they might make this peace a lasting one was always impossible, born as it was in flawed assumptions about the permanence of domination. And yet the form of the weapon produced by those who first dreamed this dream, and who believed in it, traps contemporary policymakers in the logic of the 19th century. We are, as Richard Rhodes observes, caught in a situation in which 'no one in authority believes the damned things will go off'.${ }^{57}$ But over decades, even centuries, it is entirely possible that a nuclear device will go off. The form of the weapon itself invites reversion to a logic of domination by the powerful and subversion by the weak. The acute threat of nuclear violence on the Korean Peninsula may pass. But the danger of reverting to the logic of 19th-century coercive diplomacy will remain as long as nuclear weapons do.

\footnotetext{
${ }^{54}$ Sagan \& Lewis (2016: 67-8).

${ }^{55}$ Lee $(2015: 13,35,103)$.

${ }^{56}$ Baruch (1946).

${ }^{57}$ Rhodes (2014).
} 


\section{REFERENCES}

Barnes, James (1904), The Unpardonable War (New York, Macmillan).

Baruch, Bernard (1946), 'Statement before the UN Atomic Energy Commission, June 14, 1946', American Association for the United Nations, New York; reprinted by The Atomic Archive, 2015, http://www.atomicarchive.com/Docs/Deterrence/BaruchPlan.shtml (accessed 22 April 2018).

Berney, Jesse (2015), 'Trump's Terrifying Nuke Answer at the Debate Should End His Campaign (But It Won't)', Rolling Stone, 16 December.

https://www.rollingstone.com/politics/news/trumps-terrifying-nuke-answer-at-the-debate-shouldend-his-campaign-but-it-wont-20151216 (accessed 22 April 2018).

Bernstein, Robin (2009), 'Dances with Things: Material Culture and the Performance of Race', Social Text, 27(4): 67-94. https://doi.org/10.1215/01642472-2009-055

Bierman, Noah (2017), 'Trump Warns North Korea of "Fire and Fury", Los Angeles Times, 8 August. http://www.latimes.com/politics/washington/la-na-essential-washington-updates-trump-warnsnorth-korea-of-fire-and-1502220642-htmlstory.html\#nt=card (accessed 22 April 2018).

Bleek, Philipp C. (2017), 'When Did (and Didn't) States Proliferate? Chronicling the Spread of Nuclear Weapons', discussion paper, Project on Managing the Atom, Belfer Center for Science and International Affairs, Harvard Kennedy School, Cambridge, MA and the James Martin Center for Nonproliferation Studies, Middlebury Institute of International Studies, Monterey, CA.

Chun, Christian W. (2017), The Discourses of Capitalism: Everyday Economists and the Production of Common Sense (London and New York, Routledge). https://doi.org/10.4324/9781315751290

Compton, Karl T. (1946), 'If the Atomic Bomb had Not Been Used', The Atlantic, December. https://www.theatlantic.com/magazine/archive/1946/12/if-the-atomic-bomb-had-not-beenused/376238/ (accessed 22 April 2018).

Day, Meagan, (2015), 'On Fanon and the Ethics of Anticolonial Resistance', $N+1,15$ July. https://nplusonemag.com/online-only/film-review/concerning-absolute-violence/

Fanon, Franz (2004), The Wretched of the Earth, trans. Richard Philcox (New York, Grove Press); first published in 1961 as Les Damnés de la Terre (Paris, François Maspero).

Franklin, H. Bruce (1988), War Stars: The Superweapon and the American Imagination (Amherst and Boston, MA, University of Massachusetts Press).

Franklin, H. Bruce (1989), 'Fatal Fiction: A Weapon to End All Wars', Bulletin of Atomic Scientists, 45(9): 18-25. https://doi.org/10.1080/00963402.1989.11459745

Gallagher, Adrian (2013), Genocide and Its Threat to Contemporary International Order (New York and Basingstoke, Palgrave Macmillan). https://doi.org/10.1057/9781137280268

Haberman, Maggie \& Sanger, David E. (2016), 'Transcript: Donald Trump Expounds on His Foreign Policy Views', New York Times, 26 March.

https://www.nytimes.com/2016/03/27/us/politics/donald-trump-transcript.html (accessed 22 April 2018).

Ham, Paul (2015), 'The Bureaucrats Who Singled Out Hiroshima for Destruction', The Atlantic, 6 August. https://www.theatlantic.com/international/archive/2015/08/hiroshima-nagasaki-atomic-bombanniversary/400448/ (accessed 22 April 2018).

Iser, Wolfgang (1974), The Implied Reader: Patterns of Communication in Prose Fiction from Bunyanto Beckett (Baltimore, MD, Johns Hopkins University Press).

Kaplan, Fred (2020), The Bomb: Presidents, Generals, and the Secret History of Nuclear War (New York, Simon \& Schuster).

Kehler, C. Robert (2016), 'Nuclear Weapons and Nuclear Use', Daedalus, 145(4): 50-61. https://doi.org/10.1057/9781137280268 
Kubric, Stanley (dir.) (1964), Dr. Strangelove, written by Stanley Kubric \& Terry Southern, (Hollywood, CA, Columbia Pictures).

Larison, Daniel (2017), 'The Consequences of Trump's Irresponsible North Korea Rhetoric', The American Conservative, 22 September.

http://www.theamericanconservative.com/larison/the-consequences-of-trumps-irresponsible-northkorea-rhetoric/ (accessed 22 April 2018).

Lee, David (ed.) (2015), Law of Armed Conflict Deskbook, 5th edn, International and Operational Law Department, Judge Advocate General's Legal Center and School, US Army, Charlottesville, VA. http://www.loc.gov/rr/frd/Military_Law/pdf/LOAC-Deskbook-2015.pdf

Levine, Caroline (2015), Forms: Whole, Rhythm, Hierarchy, Network (Princeton, NJ, and Oxford, Princeton University Press). https://doi.org/10.1515/9781400852604

London, Jack (1910), 'The Unparalleled Invasion', Mc Clure's Magazine, July: 308-16.

Magazine of Business (1908), 'Five Years Old', advertisement, 14(1): 796.

https://books.google.com/books?id=5MbNAAAAMAAJ\&pg=PA796\&dq=associated+sunday + magazines\&hl=en\&sa $=$ X\&ved=0ahUKEwiagt $23 \mathrm{uKjaAhWO}$ 7FMKHW2CA4AQ6AEIRzAG $\# \mathrm{v}=$ onepage \&q=associated $\% 20$ sunday $\% 20$ magazines\&f=false (accessed 22 April 2018).

Malloy, Sean L. (2008), Atomic Tragedy: Henry L. Stimson and the Decision to Use the Bomb Against Japan (Ithica, NY, and New York, Cornell University Press).

Markwica, Robin (2018), Emotional Choices: How the Logic of Affect Shapes Coercive Diplomacy (Oxford and New York, Oxford University Press).

https://doi.org/10.1093/oso/9780198794349.001.0001

Mattis, James (2018), Nuclear Posture Review, United States Department of Defense, Washington, DC, February.

https://media.defense.gov/2018/Feb/02/2001872886/-1/-1/1/2018-NUCLEAR-POSTURE-REVIEWFINAL-REPORT.PDF.

McClure's Magazine (1910), 'Schiemann on Germany and the World's Peace', June: 226.

McDevitt, Michael (2011), 'Report: Deterring North Korean Provocations', Brookings Institution, Washington, DC, 7 February.

https://www.brookings.edu/research/-deterring-north-korean-provocations/ (Accessed 22 April 2018).

Nicolson, Harold (1932), Public Faces (Boston, MA, and New York, Houghton Mifflin).

Norton, Roy (1908), The Vanishing Fleets (New York, D. Appleton and Company).

Pinker, Steven (2011), The Better Angels of Our Nature: Why Violence has Declined (New York, Viking).

Powell, Colin L. (2003), 'Remarks to the United Nations Security Council', 5 February, US Department of State Archive.

https://2001-2009.state.gov/secretary/former/powell/remarks/2003/17300.htm (accessed 22 April 2018).

Richard Rhodes (2014), ‘Absolute Power: “Thermonuclear Monarchy”, by Elaine Scarry', New York Times, 21 March.

https://www.nytimes.com/2014/03/23/books/review/-thermonuclear-monarchy-by-elaine-scarry. html (accessed 22 April 2018).

Sagan, Scott D. \& Lewis, Jeffrey D. (2016), 'The Nuclear Necessity Principle: Making U.S. Targeting Policy Conform with Ethics \& the Laws of War', Daedalus, 145(4): 62-74.

https://doi.org/10.1162/DAED_a_00412

Scarry, Elaine (2014), Thermonuclear Monarchy: Choosing Between Democracy and Doom (New York, W. W. Norton and Company).

Smith, A. Merriman (1946), Thank You, Mr. President (New York and London, Harper \& Brothers).

Stockton, Frank R. (1889), The Great War Syndicate (New York, Dodd, Mead, and Company).

Tarbell, Ida M. (1904), The History of the Standard Oil Company (New York, McClure, Phillips, and Co.). Tennyson, Alfred (1842), 'Locksley Hall', Poems, Volume II (London, Edward Moxon), 92-111. 
Thomas, Lindsay (2016), 'Forms of Duration: Preparedness, the Mars Trilogy, and the Management of Climate Change', American Literature, 88(1): 159-84. https://doi.org/10.1215/00029831-3453696

Truman, Harry S. (1945), 'Remarks Upon Receiving an Honorary Degree From the University of Kansas City', 28 June, published online by Gerhard Peters \& John T. Woolley, The American Presidency Project. http://www.presidency.ucsb.edu/ws/?pid=12190

United States Atomic Energy Commission (1954), In the Matter of J. Robert Oppenheimer: Transcript of Hearing Before Personnel Security Board, Washington D. C., April 12, 1954, through May 6, 1954. Wells, H. G. (1914), The World Set Free: A Story of Mankind (New York, E. P. Dutton and Company).

Wilson, Ward (2007), 'The Winning Weapon: Rethinking Nuclear Weapons in Light of Hiroshima', International Security, 31(4): 162-79. https://doi.org/10.1162/isec.2007.31.4.162

Wilson, Ward (2013), 'Are Nuclear Weapons Useful?', James Martin Center for Nonproliferation Studies, Monterey Institute for International Studies, Monterey, CA, 26 January.

https://www.carnegiecouncil.org/education/008/argwriting/003

To cite the article: Gordon Fraser (2020), 'The 19th-century origins of nuclear deterrence', Journal of the British Academy, 8(s3): 7-24.

DOI https://doi.org/10.5871/jba/008s3.007

Journal of the British Academy (ISSN 2052-7217) is published by The British Academy, 10-11 Carlton House Terrace, London, SW1Y 5AH

www.thebritishacademy.ac.uk 